\title{
MUSIC AS AN INTEGRATED EDUCATION TOOL FOR PRESCHOOL STUDENTS
}

\author{
Wadiyo \\ Music Department, Faculty of Languages and Arts, Semarang State University \\ Jl. Sekaran Campus Gunungpati Semarang, Indonesia, 50229 \\ E-mail: wadiyosemarang@gmail.com
}

Received: November 19, 2015. Revised: November 29, 2015. Accepted: December 4, 2015

\begin{abstract}
This article intends to uncover a concept of developing tradition-art groups in West Sumatra, which is considered that they have been left behind by modern-art groups in terms of packing aspect, presentation, and technical skills. Hence, this article reveals intervention of the academician in developing and providing support in the forms of improving skills and knowledge of the artists and art groups. The support includes improving skills and knowledge of expressing arts through giving packing techniques and arranging art performance, orientated toward educational and social extension actions. The knowledge may consist of techniques for developing movements, dance music, costumes, and make-up affecting skills of arranging and packing performance arts that can be divested in art industries. The method used in this investigation was games that aimed to cope with boredom and improve new awareness of concepts of how to pack performance arts. In addition, the case study was employed to solve problems faced by partners in the field. Moreover, practices about how to pack the arts were critical to be done through brainstorming, discussing, and lecturing.
\end{abstract}

Keywords: education message song; singing; integrative; children; preschool

How to Cite: Wadiyo, W. (2015). Music As An Integrated Education Tool for Preschool Students. Harmonia: Journal of Arts Research and Education, 15(2), 144-151. doi:http://dx.doi.org/10.15294/harmonia.v15i2.4691

\section{INTRODUCTION}

Kindergarten curriculum brings out the art indicator to be used as an education tool that is beneficial for the development of the student. In music field, its application can be done through playing music instruments and singing activity. Art education is one of the education medium to enhance children positive personality (Tarwiyah, 2004). Ideally, the actual art education must be implemented and taught since children were in childhood age since that was the time when a person's personality began to take shape (Carr dan Lehrer, 2004).

Art education is given at school, not only to develop the personality of a child but also to help multi intelligence of children to occur (Wardani, 2006). Merritt research in 'Simfoni Otak' (The Brain Symphony) book (2003) about the correlation between music and intelligence explains that music is useful in stimulating the child's IQ, EQ and SQ. Further, according to her, music which is advantageous to stimulate the interest of IQ, EQ and SQ would be more appropriate if it is played from early age, around 0 to 8 years. During the period, the talents that will be useful for children's future will begin to form. In relation the fact, it seems to be appropriate if children in preschool or kindergarten age are introduced to music. 

Every form of music can be used in stimulating children in doing activities related to gross and fine motor movements. Generally, the implication of learning music at public school, especially at preschool or kindergarten level, can be seen after it is integrated with other fields or subjects in accordance with the theme of learning that is taught by teachers during the learning process. Here, the discussed problem is about how the implementation of learning the art of music is in the context of integrative learning in preschool education, especially kindergarten.

Art education that places integrative arts as an educational tool in public schools, including in preschool or kindergarten, seems to be always implement the approach appreciation and creation or vice versa. Before understanding what is meant by appreciation and creation, one must first understand what is meant by message in art education. According to Melalatoa (1989), message here is the content of an artwork. For children, the ability in understanding the content or message of an art work might be different from one to another. It is based on the comprehension and condition of each child as an individual.

What is meant by appreciation here is assessment giver for the work of art. In order to be able to obtain it, one needs to undergo several stages. Among the stages are: introduction of text and context, understanding contain of the text and context, interpretation or comprehension, and evaluation or assessment from efficiency side for each appreciators (Bahari, 2008). What is meant by creation is new product or product that is considered to be different from others (Csikszentmihalyi in Stenberg, ed., 1999; Soehardjo, 2012). The education of creation and appreciation is believed to be able to make students to produce or create and feel their experiences. If it is developed seriously, it will influence the development of students' thinking process in other fields (Pautz in Sumaryanto, 2002). In short, through the education of creation and appreciation, it will not only develop the students' ability in making or creating an artwork, but also bring good impact for students' general intelligent.

Triana (2005) argues that education of creation at school should be done through students' activities. Here, students are required to perform the activity of arts. Meanwhile, education of appreciation is done through the activity of responding the arts. Art activity focuses on students on which they are asked to practice the art by exploring ideas and feelings. The ideas and feelings are being associated with their selves and their environment. At this stage, students' sense of sensitivity and imagination are being trained by doing experiments in the form of organizing the elements of arts. The students work by using chosen materials, voices, mediums, and spaces, on which a series of stimulus materials and works employed both individually and in groups. Students present their work to their friends in school and out of school. Based on Surya (2003) school can choose the way to implement the art activities, while students are the one who will explore the themes, ideas, and feelings by using a set of disciplines of each field of art in various combinations. A considerable number of those activities may involve the creation of music (music accompaniment) by teachers, for example, music used to accompany students' play or dance as an integrated art form among different types or mediums.

Rohidi (1999) delivers that responding art is a form of appreciation education that is usually learned by students by giving responses to the artworks. Students are stimulated to identify and explain the main characteristic of art that being presented by their selves or being presented by others. In this context, it can be the students' friends. The art can be relatively simple as long as it is based on the knowledge of the children. Students can use their own art language or express their selves by doing art activity or singing. Here, students are taught by some of the different ways of expressing art and communicating ideas and feelings of an artwork that being displayed or the song that being sung. The outcome 
will be that students are able to identify and explain some of the characteristics of art that being displayed, or in another word, appreciate it. Those ways will help to guide students to be a more creative and appreciative person towards all phenomena that they may face.

\section{METHOD}

This research was studied by implementing approach from the perspective of music and education. Research method implemented here was qualitative interpretative in relation with developmental research. Research location, research object, data collection technique, validity of technical data, and data analysis technique will be respectively described, as follows:

\section{Location of the Study}

This study is located in Semarang, including both the city and regency area. There are two schools in the city of Semarang becoming subject of the study. There are State Kindergarten of Pembina Kota Semarang and Kindergarten Tirta Dharma Kota Semarang, whereas from Semarang regency, there are Christian Kindergarten of Ungaran and Kindergarten Ihyaqul Qulub.

\section{Object of the Study}

Object of this research is closely related to the problem that becomes the main focus of this research that is about the implementation of music learning by teachers in integrative context of pre-school level, especially kindergarten.

\section{Data Collection Technique}

Data was collected by using observation technique, interview, and documentation study. Observation was conducted by fully observing the classroom. The observation focuses on how teacher uses music or song in the implementation of teaching and learning process. What kind of music or song used by teacher, how the teacher uses it, and the way (how) teacher explains the message to the students become the main focus of this observation.
The interview was also conducted here. Teachers were interviewed about the use of songs in their classrooms and the way they select it. In addition, the reason behind the process of song selection as well as the expected outcome had by teachers after teaching by using songs also became the main content of the interview. Other than this was a question related to songs which were frequently sung by teachers. This was considered to be important for the answers derived from this particular question could be used to find out the kinds of message that was emphasized more by teachers.

Further, documentation study technique was also applied here in order to find out the availability of songs had by the schools, especially for the songs which were frequently used in integrative teaching during the teaching and learning process. What were seen by documentation study were the written songs by teachers as well as songs in the form of tape or compact disk which had been already owned by the school.

\section{Data Validation Technique}

In validating the data, triangulation was employed to see whether there was a pattern resulted from observation conducted by researcher regarding to the teaching and learning process in the actual classroom. It also used to see the similarity and difference in using the song as media in teaching integrated themes for students from one school to another. Later, after all data from different teachers, headmasters, and school was able to be compiled, it was then analyzed and validated (checked) in order for the compatibility and triangulation form from many sources to be seen.

\section{Data Analysis Technique}

The data obtained from the study was analyzed by developing previous theory by Nasution (1996); Bogdan \& Biklen (2007); and Miles \& Huberman that had been translated into bahasa Indonesia by Rohidi (1992), that is interactive analysis. In interactive analysis, an analysis will be 
started from data collection, continued by data reduction, data display, and finally conclusion or verification. The process also involved checking and rechecking the source of data while adding or eliminating the relevant data.

\section{RESULTS AND DISCUSSION}

Based on the data analysis that had been done by researcher, the results of the study were able to be obtained. Following the procedures of presenting research results of qualitative method, results of the study here would be followed up by discussion in order to be able to analyze the results deeper. Here, even if the initial planning of this research was for both developmental and qualitative research, however, in this paper, parts of results and discussion will focus more on the qualitative part. Thus, the following would be the results and discussion to answer the research question in this study about how the implementation of music learning in integrated learning context in preschool level especially Kindergarten that was done by the teacher is.

The development of music teaching materials for the curriculum that being used for preschool students, especially Kindergarten is open for interpretation. However, although the curriculum is open for interpretation, the curriculum itself has considered character education and development of national identity. It is also significantly implemented in preschool education in this context Kindergarten education.

Regarding to the development of art teaching material in preschool education level, especially Kindergarten, the curriculum has been understandable. According to Tarwiyah (2004), Kindergarten curriculum which points out the indicator of art, emphasized on how the art can be used as an educational tool which is useful for the student's development. It is not used to force students to be able in doing art. In its application during the learning process, music can be taught through singing and playing music instrumentals, but, the main focus in during the learning is not on the music itself, but more to the educational messages that is delivered through the music or song.

All of the teaching materials that developed today are contained in the Matrix or Annual Program of Kindergarten. That art is taught by interpreting the matrix which is divided into Developmental scope, Achievement Level Developments, indicators, themes, and Estimated Time of Week. Developmental scope is composed of religious values and morals, which consists of the physical gross motor, fine motor, and physical health. Additionally, within the scope of development, there is cognitive that consists of general knowledge and science, the concept of shapes, colors, sizes, and patterns. In this developmental scope, there are also the concepts of numbers, symbols, and letters. There is also a scope associated with the development of language. There are some languages that consist of language acceptance, language expression, and literacy. Another aspect other than those already mentioned earlier is all scope under social developments.

According to Carr and Lehrer (2004) it is actually ideal that arts education must be instilled since childhood because here is the time when a person's personality begins to take shape. What is done and developed in learning process for children in preschool level in this context is Kindergarten, on which art is used as education media, has been regarded as something appropriate. Education of art which is given at school also meant to help the students' multi intelligent (Wardani, 2006).

Multi intelligence of art as proposed by Wardani has been proven through the result of research conducted by Merritt (2003). Merritt's study shows that music helps children in stimulating much intelligence. In regard to that interest, it will be more appropriate if music is being listened since the early age. The basic thinking of curriculum for the preschool level also explains that music in any forms can be used to stimulate the children to do an activity 
that is associated with gross and fine motor movement.

In the actual implementation, the learning process of art in public school especially for preschool or Kindergarten level has been integrated with other fields in accordance with the learning theme that should be delivered by the teacher during the learning process. Based on a researcher's study in kindergartens that became the sample of this research, theories stated by experts had been implemented. By singing, students were not only invited to sing, but also to analyze what was contained as an educational message inside the song or art taught at the classroom. The analysis was given both verbally and non-verbally by teachers to be understood by the students.

In matrix or kindergarten annual program is explained the level of achievement of the development. The scopes of development related to religion values and morals describes the level of achievement development that comprises some aspects, i.e. knowing God through religion, imitating worship movement, praying before and after doing something, knowing good/polite behavior, familiarizing themselves in well behavior, and greeting and returning the greetings. The aspects above were taught by using songs and also applied through verbal or nonverbal language. This is why making art, music, and song as an integrated tool in kindergarten education is important.

Art or music or song is integrated in learning process to achieve various purposes that are in line with the curriculum. The real implementation of art education through appreciation and creation approach has been in line with the expectation of Bahari (2008) and Soehardjo (2012). Students felt the song with expression in accordance with the message of the songs that were sung, like happy, amazed, and sometimes proud. Creative of students could also be seen when they were singing the song while doing movements that related to the content or the message of the songs. This is one form of responding art in appreciation and creation context as being stated by Pautz (in Sumaryanto, 2002); Rohidi (1999); Triana (2005).

It is so real that through the expression of art done by students, the message of the song delivered to the students is proven. Similar to what is explained by Melalatoa (1989), through the message of art, everything that is inside of the art will be accepted easily and happily by its appreciators. Every child as an individual should not always be the same in accepting the message cognized (Altenbernd and Lewis, 1970). All of those things depend on the background and condition of each child that naturally one and others are probably different.

In addition to what has been proposed, in learning curriculum for children in preschool education, especially in this context is Kindergarten, it states about physic development scopes that correlated with gross motor. There are some aspects of the achievement level of development, those are: (1) imitating the movement of animal, trees blowing in the wind, flying plane, and etc, (2) imitating hang movement (clinging), (3) doing jump, slide, and coordinated run, (4) throwing something directionally, (5) catching something accurately, (6) doing anticipated movement, (7) kicking something directionally, and (8) utilizing the playing tool outside of the class.

Physic development scope instead of the gross motor is fine motor. In achievement of development scope of fine motor, there are (1) making vertical, horizontal, curved, oblique, and circle lines, (2) copying the shape, (3) coordinating eyes and hands to do a complicated movement, (4) doing manipulated movement to create a shape by using all kinds of media, and (5) expressing their shelves by making art work using all kinds of media. In the scope of physical development in relation to gross and fine motor, through singing and expressing using song as stated by Csikszentmihalyi in Stenberg (1999) and Surya (2003), as a form of creativity, children are also being stimulated by the teacher by giving the freedom to the students to express 
the song. Each child is expressing songs with their own ways. Some of them are laughing, funny, screaming, holding their friends, or even by hitting their friends in joking context, and many other ways that have been done by the students regarding their expression in understanding and feeling the song that they are sung.

Beside of the scope of fine motor development, there is the scope of the development of physical health. The level of the developmental achievement is correlated with three physical healthy, those are: (1) it has suitability between age and weight, (2) it has suitability between age and height, and (3) it has suitability between weight and height. It is clear that generally all aspects related to physic is just gross motor, fine motor, and physical healthy. The following in physical development with achievement level is continued by cognitive aspect. Gardner (1997) explained that "music may be a privileged organizer of cognitive processes, especially among young people" (p. 9).

Scope of cognitive aspect development as has been stated on the front is divided into three aspects, those are; (a) general knowledge aspect and science, (b) concept of shape, colour, size and pattern, (c) concept of numbers, symbols, and letters. General cognitive aspect and science, the development of achievement results is to: (1) know the thing based on its function like a knife to slice, (2) uses things as a symbolic game like chair as a car, (3) understand about symptom causation related to their selves, (4) know the simple concept of daily life drizzle, rain, dark, light, twilight, and etc, (5) create something in accordance with his own idea. It is also supported by Fortner (1997) who suggests that science teaching can be made more relevant through integration teaching, while Yasso (1991) encourages integration to increase intrinsic motivation for science.

The achievement of development level of aspects of concept of shape, colour, size, and pattern, are to: (1) clarify things based on its shape or colour or pattern, (2) classify objects into similar groups or groups in pairs, (3) know people in $\mathrm{AB}-\mathrm{AB}$ and $A B C-A B C$ patterns, and (4) understand sort objects based on five variations in the size or colour.

The others development scope about this is regarding to the concept of numbers, symbols, and letters in which at the achievement level of development covers: (1) knowing the concept of many and few, (2) numbering many things from one to ten, (3) knowing the concept of numbers, (4) knowing symbols of numbers, and (5) knowing the symbols of letters.

The next is language development scope, in which it is connected with accepting language, expressing language, and literacy. Accepting language in achievement of development level covers: (1) repeating the simple sentence, (2) answering simple questions, (3) expressing feeling by using the adjective (naughty, stingy, kind, brave, good, ugly, and etc), (4) mentioning the words known, (5) expressing opinions with others, (6) stating the reason for something to be desired or disapproval, and (7) retelling the story or fairy tale that ever heard.

Still in scope of language development side, it is correlated with literacy. Level of literacy development achievement covers: (1) showing independent behaviour in choosing an activity, (2) sharing, helping, and help a friend, (3) showing the enthusiasm in playing competitively in a positive way, (4) controlling the feeling, (5) obeying the rules of the game, (6) showing the self confidence, (7) protecting their selves from the environment, and (8) respecting other people. Johnson and Johnson 1975 argued that a truly cooperative behavior occurs when there is (1) personal incentive to achieve; (2) positive interdependence so that each individual has a different but integral role in the group; and (3) a common goal. Making music provides a positive example of all these principles of cooperative learning. When music is studied and played to represent an idea, concept, or historical period, it can also provide a common goal for academic objectives. 
In matrix or this annual program, essentially related to the scope of the development described at the level of achievement of development and explained to be carried out with the written indicator as guidance to be developed in the teaching learning process. Started from the development scope that explained using its basic indicators, all of those things are using the expected theme and time in a week during the learning practice. The theme that determined in annual learning program is about me, my environment, my need, animal, plant, recreation, my homeland, and universe.

It is not stated implicitly in the matrix or annual programs about a name of learning material, but the teacher should be able to translate by their selves in the practice of the daily learning process. Based on the matrix or annual program, the teacher can select about what and how the learning practice should be conducted. For the learning field in its relation to art, the teacher could be selected from what is contained in the matrix/ program, especially from indicators point that should be run by the teacher.

Based on many indicators that should and must be run by teachers, it can be stated at one point that related to the art learning process, especially music that sometimes should be integrated with other material, like indicators of singing simple religion song. This is included in the achievement of development about know God through religion that they believed in scope of religion values and morals development. Kilpatrick (1994-95) suggested that music should be sung or played together, channel the emotions toward hope and caring, and tell a morally satisfying story. Active participation is not meant to substitute for recitals or concerts, but is to bring students and teachers together in the cooperative and constructive act of making music as an integrated part of the regular classroom.

Another indicator that included in the matrix or annual program that should be done by teachers in teaching learning process is as the example indicator of mov- ing heads, hands, foot while following the rhythm of the music or rhythms. It shows that music and dance material is lessons that cannot be separated. Still in the same indicator point, there is also something that same. It is about express their selves freely according to the rhythm of music. This indicator is included in the series of achievement of development level in utilizing playing tool outside of the class in physic development scope related to the gross motor.

Making sound using all kinds of tools as an indicator that should be done in the learning process related to self expression by working in the arts using all media in physical development scope and also related to the fine motor. Another indicator that related to this is make a simple music instrument like to make "krincingan" of bottle caps, playing music using simple and sober musical instrument, and clapping with two patterns to create patterns. Burton (2001) suggests a number of benefits of integration, including applying basic skills to real-life situations, raising standards, enhancing teacher creativity, developing less teacher isolation and providing a more positive classroom climate. According to Barrett (2001), national music standards dealing with 'understanding relationships between music, the other arts, and disciplines outside the arts', and 'understanding music in relation to history and culture' embrace the concept of quality integration for students to develop a deeper understanding of subjects through their interaction with each other.

Music is also integrated through development scope in expressing language in achievement of development level using feeling by adjective with the indicator in singing a full children's song, fabricate or create poetic based on the ability of children, and utter words of songs. Those indicators are the only indicators that correlated with arts, especially music material that contained in the matrix/ annual program of Kindergarten. Besides, it is blended with other materials, the practice of its learning process on the idea of the appreciation and 
creation process is melting in its contextual learning and integration.

\section{CONCLUSION}

The model of the development of art teaching materials in Kindergarten is referring to the theme that relates to children's life and their environment. Music material, once used as the main subjects of integrative and other materials to instill the knowledge and example of behavior as well as aesthetic educational tool in conjunction with the scope of development and the level of achievement of development as outlined in the matrix / annual program.

For example, scope of development that given music is religion development scope especially on the level of the development of religion values and morals that done by singing song that contained religion. Another scope of development is containing of a combination of music and dance, mainly to develop the gross and fine motor skills, and added with the main musical material that sang to develop the potential of language skills.

\section{REFERENCES}

Altenbernd and Leslie L. Lewis. (1970) Introduction to Literature: Poems. Mac. Millan \& Co. LTD Second Edition.

Bahari, N. (2008). Kritik Seni. Yogyakarta: Pustaka Pelajar.

Barrett, J. R. (2001). Interdisciplinary work and musical integrity. Music Educators Journal, 87(5).

Burton, L. H. (2001). Interdisciplinary curriculum: Retrospect and prospect. Music Educators Journal, 87(5).

Van De Carr, F. R. and Lehrer, M. (2004). Cara Baru Mendidik Anak Sejak Dalam Kandungan. Kesenian. Jakarta: Pusat Kurikulum Balitbang Depdiknas.

Fortner, R. W. (1997). Arts and sciences: A natural connection. Science Activities, 34(3).

Gardner, H. (1997). Is Musical Intelligence Special? in V. Brummett (Ed.), Ithaca.
Conference '96: Music as Intelligence (1-12). Ithaca, New York: Ithaca College Press.

Johnson, D.W. \& Johnson, R.T. (1975). Learning Together and Alone: Cooperation, Competition and Indioidualizatum. Englewood Cliffs, NJ: Prentice Hall.

Kilpatrick, W. (1994-95). Music and Morality. American Educator IH (4).

Melalatoa, M. J. (1989). Pesan Budaya dalam Kesenian. Berita Antropologi. Jakarta: JAFIS \& IP Universitas Indonesia.

Merritt, S. (2003). Simfoni Otak. Bandung: Kaifa.

Rohidi, T. R. (1999). Fungsi Seni dan Pendidikan Serta Implikasinya in Pengembangan Kebudayaan. Paper presented on workshop "Pengembangan Bahan Ajar Pendidikan Seni Rupa" Semarang on April 14 -16, 1999.

Soehardjo, A.J. (2012). Pendidikan Seni: Dari Konsep Sampai Program. Malang: Universitas Negeri Malang.

Sternberg, R. J (ed). (1999). Handbook of Creativity. Cambridge: Cambridge University Press.

Sumaryanto, T. (2002). Pemupukan Kreativitas Anak Melalui Pembelajaran Musik. Harmonia: Jurnal Pengetahuan dan Pemikiran Seni Harmonia, 2(3).

Surya, Adi. (2003) Implementasi Seni Di Sekolah. Jakarta: Andika.

Tarwiyah, Tuti. (2004). Analisis Nilai-nilai Pendidikan Dalam Lagu-lagu Daerah Betawi. Harmonia: Jurnal Pengetahuan dan Pemikiran Seni Harmonia, 6(1).

Triana, D. D. (2005). Meningkatkan Kreativitas Dalam Pembelajaran Tari Melalui Metode Proyek Pada Anak Pra-Sekolah. Harmonia: Jurnal Pengetahuan dan Pemikiran Seni, 5(1).

Wardani, Cut Kamaril. (2006). Pendidikan Seni Berbasis Budaya in Meningkatkan Multi Kecerdasan. Jurnal Kagunan, I(1).

Yasso, W. E. (1991). Discovering Science in Art, Literature, and Music. Science Activities. 28(1), 